\title{
Teachers' Teaching Quality in Improving Learning Quality
}

\author{
Firzayuni Kurniati \\ MTs Darussalam Lahat, Indonesia \\ Email: firzayuni77@gmail.com \\ Happy Fitria \\ Universitas PGRI Palembang, Indonesia \\ e-mail: happyfitriamufly@univpgri-palembang.ac.id \\ Achmad Wahidy \\ Universitas PGRI Palembang, Indonesia \\ e-mail: ahmadwhidy@univpgri-palembang.ac.id \\ Article History: Received on 14 December 2021, Revised on 30 January 2022 \\ Published on 25 February 2022
}

\begin{abstract}
The goal of this study was to evaluate and analyze: (1) the effectiveness of teachers in increasing the quality of learning at MTs Darussalam Lahat; (2) the barriers encountered by teachers; and (3) the approach applied. This is a qualitative research method using a descriptive approach. The following data gathering methods were used: (1) observation; (2) interviews; and (3) documentation. Techniques for analyzing research data include (1) data reduction; (2) data presentation; and (3) data verification/conclusion. According to the findings of the study, (1) teachers are capable of planning classes, carrying out learning, evaluating learning, following up on the learning outcomes supplied, and providing advice and counseling; (2) due to restricted facilities, not all instructors can participate in activities such as training, MGMP, and seminars. (3) the technique adopted by teaching teachers to improve the quality of learning at MTs Darussalam Lahat is to seek infrastructure that is not already present in schools, such as multiplying books as learning medium to fulfill the learning demands of students.
\end{abstract}

Keywords: Quality of Teaching, Quality of Learning, Teacher

\section{A. Introduction}

The issue of education and teaching is a very complex one that is influenced by a variety of circumstances. The teacher is one of these influences. The teacher is a teaching component that plays a significant and primary function, since the teaching and learning process is heavily influenced by the instructor.

The teacher's role in the teaching and learning process is to impart subject information to pupils through communicative exchanges. The smoothness of communication exchanges that have an influence on the message supplied by the instructor is highly important to the teacher's success in presenting the subject (Hamid, 2010).

One of the elements influencing student learning outcomes is school. The more the student's learning aptitude and the quality of instruction in schools, the greater the student's learning results (Wasliman, 2012). A teacher has a moral commitment to society to carry out his 
responsibilities with unwavering effort, honesty, and sincerity. As a result, we may conclude that possessing information, no matter how extensive, is insufficient to qualify you as a teacher.

In general, education seeks to maximize pupils' potential. As a competent teacher, he naturally wants as many of his students to pass or obtain excellent grades as possible. He would be upset if several of his students had lower grades or did not pass. In this instance, the teacher is expected to develop the potential of children, and he must be skilled at restricting himself so that his desire to create students with high marks does not interfere with his ability to do so (Sukardi, 2016).

Teachers must possess four competencies: pedagogical competence, personality competence, professional competence, and social competence. Then there's the question of whether Indonesian teachers' competency criteria fulfill the four competencies listed above. Of course, actual actions must be taken to increase the quality and ability of instructors.

The Ministry of Education and Culture recognizes this and expects it by mapping Indonesian teacher competency requirements. Various trainings have been conducted to increase teacher competency, including teaching training that is relevant to the times, such as the use of technology. The normative issue in the form of teacher certification as a guarantee of passing the competency test as a professional teacher emerges later in the context of carrying out the professional tasks of a teacher or educator. Even if it offers fresh optimism in terms of teacher welfare, it is also the result of educators' or instructors' fear and uncertainty. Teachers must be qualified in accordance with specified criteria.

A teacher's primary responsibility is to educate pupils, which implies that the teacher not only shares information with students (knowlegde), but also educates students in terms of attitudes and behaviors (Rizaldi, 2014). The quality of instructors in the classroom is a significant factor in efforts to improve the nation's quality of life. This is because the teacher is the driving force behind all of the nation's children's education and learning endeavors. This skill does not just exist; it is the result of a protracted process of education and learning. We may obtain figures who are knowledgeable in their subjects via this approach, which improves the overall state of a school (Usman, 2012).

The government has made efforts to improve teacher quality in a variety of ways, including providing block grants to schools as stimulus funds to implement teacher professional development programs, forming subject teacher associations, establishing teacher scientific forum organizations, and publishing scientific journals. Working group programs for teachers and teachers to empower teachers have been implemented in practically every district/city thus far.

The numerous teacher quality development programs essentially seek to increase teachers' talents and skills in planning, creating, implementing, and overseeing the learning process in order to promote the improvement of education quality in each school unit (Sumardin, 2016). According to Danim (2012), in the classroom, all components of learning collide and process. In the classroom, teachers of all talents, students of all backgrounds and potentials, curriculum with all of its components, techniques and approaches, media with all of their tools, and materials with all of their learning resources meet and interact. 


\section{B. Methods}

The qualitative research method with a descriptive approach was employed in this study. According to Prastowo (2011), a descriptive approach is one that is used to investigate the current state of a group of people, an item, a set of conditions, a system of ideas, or a class of occurrences. Sukmadinata (2011) defines qualitative research as study that describes and analyzes occurrences, events, social activities, attitudes, beliefs, perceptions, and ideas both individually and in groups. According to Moleong (2011), qualitative techniques are research approaches that generate descriptive data from individuals in the form of written or spoken words and observed behavior. The created data takes the shape of words, images, and human behavior.

According to the preceding definition, this research technique is a qualitative descriptive method. Qualitative methods are used to analyze data in the form of information, such as the results of observations and documentation, using two ways of thinking, namely deductive thinking, namely a way of thinking that departs from general knowledge and is based on general knowledge that wants to assess an activity, and inductive thinking, namely a way of thinking that is based on general knowledge that wants to assess an activity. in particular (Hadi, 2011). Inductive reasoning is a mode of thinking that starts with specific facts, concrete happenings, and then draws broad generalizations from those specific facts (Hadi, 2011). As a consequence, this research refers to the findings of field studies conducted in order to acquire research data, ensuring that the data and validity of the study are truly legitimate for research.

The data used as a reference in this study are the findings of research on the quality of teaching teachers in improving the quality of learning at MTs Darussalam Lahat, such as interview data, documentation data, such as photos of teacher documentation in teaching, photos of documentation of research sites related to infrastructure, and other supporting data. Furthermore, the data acquired from the study's findings are the result of interviews with school administrators and teachers at MTs Darussalam.

According to Djamarah (2010), data are required in a research. Techniques are required for data collection, both in terms of delivering data and categorizing the data that has been acquired. Furthermore, Sugiyono (2015) defines the data collection method as the method used to collect data, whereas the data collection technique is the approach utilized to carry out the chosen method. In brief, a method is a way, but a technique is a way to carry out a selected approach. Because this is a field study, the needed data can only be acquired in the field, at the research site. The following data gathering approaches were used in this study: (1) an interview or an interview; (2) recording; (3) observation

\section{Results and Discussion}

Based on the research findings, it is clear that the teaching instructors' effectiveness in increasing the quality of learning at MTs Darussalam Lahat is high.

\section{Teachers' Teaching Quality in Improving Learning Quality at MTs Darussalam Lahat}

As previously stated, the research findings reveal that the quality of instructors teaching at MTs Darussalam Lahat is good in terms of planning and implementing the learning imparted to students. The learning objectives presented have referenced competence standards, indicators, 
and domain goals, and they are in line with the curriculum. Furthermore, effective instructors are those who give learning materials based on objectives, arrange learning materials systematically, educate using learning materials based on the curriculum, and provide enrichment to pupils. The teacher's teaching strategies/methods vary, making the learning process more pleasurable.

This is supported by the findings of interviews with school administrators, who noted that instructors' capacity to supervise pupils in the learning process differs, with teachers at MTs Darussalam Lahat having a varying degree of skill. However, he may be regarded to have given it his all. Teachers confront the challenge of managing students since not all students can be controlled, and pupils are sometimes more inclined to be among peers they already understand. The instructor's technique for controlling students in the learning process is to utilize a jigsaw learning pattern, in which there are students who are brighter (expert teams) in the study group, so that they may aid their friends if they do not comprehend the learning material offered by the teacher.

The learning medium utilized by the instructor is tailored to the sort of assessment employed for each course. The instructor examines the end-of-lesson outcomes in relation to the objectives, includes the method of assessment, includes the kind of evaluation, and modifies the evaluation criteria. The teacher's ability to teach while opening the lesson may be stated to be good, where the instructor first offers initial motivation, perspective, expresses the learning objectives supplied, and provides reference for learning materials to be delivered. The teacher does not only sit on the bench to provide learning materials to liven up the learning environment; the teacher's attitude in the learning process is an important aspect of gauging teacher teaching competency. Based on research findings of teacher attitudes in learning, the teachers at MTs Darussalam Lahat can be said to be good in terms of clarity of articulation in conveying the material, body movements that do not interfere with students' attention, teachers' appearance, and mobility of teaching positions.

Learning materials are delivered in line with the phases established in the lesson plans, indicating mastery of teaching quality learning materials in increasing the quality of learning at MTs Darussalam Lahat. The clarity with which learning materials are explained is commendable, and the examples provided are likewise quite clear and readily comprehended by pupils. Instructors' insight into presenting learning materials is strong, however there are still teachers who require educational training to improve their insights. Activities in the learning process supplied by the instructor can be deemed to be sufficient by altering the method of learning materials delivered. It is sufficient to present resources in accordance with student learning requirements that refer to the goals/indicators that have been established. Teachers that educate pupils how to respond to and reply to their queries are considered good.

Teachers' capacity to educate in increasing the quality of learning at MTs Darussalam Lahat in employing learning media with regard to media principles may be stated to be good. The requirement/suitability of the media's usage with the material delivered is adequate. Instructors who teach have strong abilities in the use of learning media, and teachers who teach assist raise students' attention in learning activities. At MTs Darussalam Lahat, the quality of teaching instructors in increasing the quality of learning always gives an assessment in line with the goals stated. Teachers employ the method and manner of evaluation set by the Ministry of Religion in their classrooms. The assessment offered at MTs Darussalam Lahat is in conformity with the guidelines in the lesson plans. It is possible to say that the teacher's capacity to teach 
closing learning activities by revisiting the content that has been presented is good. Students are given opportunity to ask and answer questions by the teacher. At the end of the learning exercise, the teacher provides a conclusion. The instructor assigns homework to pupils both individually and in groups at the end of the learning process that has been presented. The teacher gives information on the topic that will be covered at the next meeting. The teacher encourages pupils to work hard in class.

This is consistent with the principal of MTs Darussalam Lahat, who stated that the competence of instructors to manage student learning facilities during the learning process is sufficient, where infrastructure limits are a standard for student learning facilities. Teachers' difficulties are often merely a plea to pupils to be wise in handling their learning facilities. The teacher's technique is to photocopy the handbook and assign pupils to work in groups or individually to learn. In general, instructors may be considered to be competent at building and maintaining learning environments in which each teacher explains learning content and pupils actively listen and pay attention to the teacher. The difficulty is that not all active pupils comprehend the information offered by the teacher. When the instructor leaves the classroom for any reason, there is generally some noise in the classroom. If the instructor is not in the classroom, the teacher will usually ask one of the pupils to duplicate the subject matter on the blackboard.

\section{Teachers' Obstacles to Improving Learning Quality at MTs Darussalam Lahat}

According to the research findings, the most of the challenges that instructors experience in increasing the quality of learning are connected to the current infrastructure at MTs Darussalam Lahat. The principal further mentioned that the inadequate facilities and infrastructure set a standard for student learning facilities.

A contributing reason to the barriers in increasing the quality of learning at MTs Darussalam Lahat is the absence of supporting facilities for learning activities based on existing content in the planning of learning activities, such as teaching aids that are still insufficient. According to the relevant research, namely the study conducted by Sultoni et al, (2020), with the title "The Influence of School-Based Management and Work Motivation Toward Teacher's Performance," it is concluded that there is an influence of school-based management (MBS) and shared motivational work on the performance of SDN teachers on Rimau Island. Researchers might infer from this study that there are parallels and contrasts between earlier researchers and contemporary research on the effect of management. The distinction between earlier and present research is in the item employed as a source of research data and the location of study.

\section{Teachers' Strategies for Increasing Learning Quality at MTs Darussalam Lahat}

According to the research findings, teaching instructors' tactics for increasing the quality of learning at MTs Darussalam Lahat include pursuing infrastructure that is not yet accessible in schools, such as multiplying books as learning medium to satisfy students' learning demands. The teacher's technique for controlling students in the learning process is to utilize a jigsaw learning pattern, where there are students who are brighter (expert teams) in the study group, so that they may aid their friends if they do not grasp the learning material being taught. presented by the instructor. 
The teacher's delivery approach for learning content is to provide examples of the subject delivered so that pupils can grasp it. At the time, the instructor delivers the subject through lectures and gives discussion and question and answer chances to students, allowing them to exchange perspectives with colleagues and address current difficulties. When the instructor employs visual media to clarify the topic offered, pupils often have a very clear comprehension of the subject matter.

This is consistent with Karawati's (2014) assertion that what happens in the classroom influences learning results. As a result, the class must be managed appropriately, professionally, consistently, and sustainably. Positive connections between instructors and students can only be developed if both parties have a positive mindset. Although students have flaws, they also have numerous benefits, and it is far preferable to cultivate positive potential in students than to focus on their flaws. Teachers make a significant contribution to the achievement of school-based learning. Teachers have a critical role in assisting students' growth so that they can achieve their life objectives to the best of their abilities (Hamalik, 2014).

Looking at the findings of the research, it has been proved by the findings of relevant earlier studies, specifically (Tursinawati, 2016). According to the findings of this study 1) almost all instructors manage the class very effectively, but there are some teachers who are not very good at controlling the class, as seen by their inability to assist youngsters focus their attention during the learning process; 2) Learning process limits imposed by teachers; children with special needs have different understandings than other pupils. As a result, it is difficult for ABK to accept learning since some learnings are not appropriate for their capacities. This study is comparable to current studies in that both are looking at the quality of instructors in the learning process. The current study, on the other hand, looks at the effectiveness of instructors in increasing the level of learning at MTs Darussalam Lahat.

Other studies, such as Warsono (2016), show that the quality of teachers in the classroom can increase the quality of learning in terms of student learning results. According to the findings of his research, classroom management planning is carried out by arranging facilities, teaching management, and student arrangements, classroom management implementation is carried out by applying several classroom management principles and approaches, and continuous supervision is carried out. Supporting and inhibiting factors in classroom management are the physical environment, social conditions, emotional, and organizational factors. This study is comparable to current studies in that both are looking at the quality of instructors in the learning process. The current study, on the other hand, looks at the effectiveness of instructors in increasing the level of learning at MTs Darussalam Lahat.

Several theoretical studies have also supported the findings of this study, as stated by Sani (2017), that instructors as learning agents must be competent, and competence would show as mastery of knowledge and professionalism in carrying out their tasks as teachers. Teachers' competences can be earned through formal education or by experience. Academic credentials, competences, educator certifications, physical and mental health, and the capacity to accomplish national education goals are all required competencies for teachers under current legislation (Fitriana et al, 2022; Wachidi et al, 2020).

Quality education may be achieved if schools adhere to government requirements. The government released Regulation No. 32 of 2013, which describes the National Education 
Volume 3 (2) 2022

E-ISSN: 2723-6919 P-ISSN: 2746-0827

System Law in detail, namely the standard process. The process standard includes national education standards or regulations governing the implementation of learning in schools in order to meet student graduation requirements (Masuri et al, 2022; Ernawati et al, 2022; Sriwahyuni et al, 2019).

\section{Conclusion}

Based on the study's findings, it is possible to conclude that the quality of teaching teachers in improving the quality of learning at MTs Darussalam Lahat is good, with teachers delivering learning materials in accordance with the lesson plans, syllabus, and rules referred to by the Ministry of Religion and the Ministry of Education and Culture of the Republic of Indonesia. Teachers are capable of planning courses, carrying out learning, evaluating learning, following up on the learning outcomes given, and providing advice and counseling. The poor infrastructure of MTs Darussalam Lahat is an impediment to teaching instructors' efforts to improve the quality of learning. As a result, not all teachers can participate in activities such as training, MGMP, and seminars. Not every teacher who teaches has a teaching credential. The teaching instructors' method for increasing the quality of learning at MTs Darussalam Lahat is to seek infrastructure that is not already present in schools. The teacher's technique for controlling pupils during the learning process is to use the jigsaw learning pattern.

\section{E. Acknowledgement}

Thanks to Principal of MTs Darussalam Lahat Rector Universitas PGRI Palembang, Director of Postgraduate Program and Chief of Study Program Management of Education Universitas PGRI Palembang and friends who have helped us to do this meaningful project.

\section{References}

Danim, S., \& Yunan, D. (2012). Administrasi Sekolah dan Manajemen Kelas [School Administration and Classroom Management]. Bandung: Pustaka Setia.

Djamarah, S. B. (2010). Metode dan Statistika Penelitian [Research Methods and Statistics]. Jakarta: Rajawali Pers.

Ernawati, E., Harapan, E., \& Kesumawati, N. (2022). Improving the Quality of Learning in Primary Schools. Journal of Social Work and Science Education, 2(3), 269-274. https://doi.org/10.52690/jswse.v2i3.258

Fitriana, F., Harapan, E., \& Kesumawati, N. (2022). Improving the Quality of Learning through Teacher's Guidance. Journal of Social Work and Science Education, 2(3), 275-280. https://doi.org/10.52690/jswse.v2i3.259

Hadi, S. (2011). Penelitian Kualitatif [Qualitative Research]. Bandung: Alfabeta.

Hamalik. (2014). Kepribadian Guru Indonesia [Indonesian Teacher Personality]. Jakarta: Raja Graffindo Persada.

Hamid. (2010). Kemampuan Dasar Mengajar: Konsep Dasar Teori dan Praktek [Basic Teaching Skills: Basic Concepts of Theory and Practice]. Bandung: Alfabeta. 
Karawati, E. (2014). Manajemen Kelas [Class Management]. Bandung: Alfabeta.

Masuri, M., Fitria, H., \& Mulyadi, M. (2022). Improving the Quality of Education in Public Primary School. Journal of Social Work and Science Education, 2(3), 259-263. https://doi.org/10.52690/jswse.v2i3.256

Moleong, L. (2011). Metodologi Penelitian Kualitatif [Qualitative Research Methodology]. Bandung: Remaja Rosdakarya.

Prastowo, A. (2011). Penelitian Kualitatif: Teknik Mendesain Pembelajaran [Qualitative Research: Learning Design Techniques]. Yogyakarta: Diva Press.

Rizaldi, A. (2014). Dari Guru Konvensional Menuju Guru Profesional [From Conventional Teacher To Professional Teacher]. Jakarta: Grasindo.

Sani, B. (2017). Kompetensi Pedagogik, Teori dan Praktik Untuk Peningkatan Kinerja dan Kualitas Guru [Pedagogic Competencies, Theory and Practice for Improving Teacher Performance and Quality]. Jakarta: Kata Pena.

Sriwahyuni, E., Kristiawan, M., \& Wachidi, W. (2019). Strategi Kepala Sekolah Dalam Mengimplementasikan Standar Nasional Pendidikan (SNP) Pada SMK Negeri 2 Bukittinggi [The Principal's Strategy in Implementing the National Education Standards (SNP) at SMK Negeri 2 Bukittinggi]. JMKSP (Jurnal Manajemen, Kepemimpinan, dan Supervisi Pendidikan), 4(1), 21-33.

Sugiyono. (2015). Metode Penelitian Pendidikan, Pendekatan Kuantitatif, Kualitatif dan $R$ \& $D$ [Educational Research Methods, Quantitative, Qualitative and R\&D Approaches]. Bandung: Alfabeta.

Sukardi. (2016). Guru Powerful, Kunci Sukses Menjadi Guru Efektif [Guru Powerfull, Kunci Sukses Menjadi Guru Efektif]. Bandung: Kolbu.

Sukmadinata, N. S. (2011). Metode Penelitian Pendidikan [Educational Research Methods]. Bandung: Remaja Rosdakarya.

Sultoni, M. Lian, B. Mulyadi. (2020). The Influence of School Based Management and Work Motivation towards Teacher's Performance. International Journal of Educational Review, 2(2), 183-191.

Tursinawati. (2016). Kemampuan Guru dalam Mengelola Kelas Untuk Siswa yang Berkebutuhan Khusus di SDN 16 Banda Aceh [Teacher's Ability in Managing Classes for Students with Special Needs at SDN 16 Banda Aceh]. Jurnal Manajemen Pendidikan, $3(1), 252-267$.

Usman, M. U. (2012). Menjadi Guru Profesional [Become a Professional Teacher]. Bandung: Remaja Rosdakarya. 
Journal of Social Work and Science Education

Volume 3 (2) 2022

E-ISSN: 2723-6919 P-ISSN: 2746-0827

Wachidi, W., Rodgers, A., \& Tumanov, D. Y. (2020). Professional competence understanding level of elementary school in implementing curriculum 2013. International Journal of Educational Review, 2(1), 99-105.

Warsono. (2016). Pengelolaan Kelas dalam Meningkatkan Belajar Siswa [Classroom Management in Improving Student Learning]. Jurnal Manajemen Pendidikan, 3(1), 118132.

Wasliman, I. (2012). Problemantika Pendidikan Dasar [Basic Education Problems]. Bandung: Universitas Pendidikan Indonesia. 